\title{
SMOKING PREVALENCE AND DETERMINANTS AMONG UNIVERSITY STUDENTS IN CAIRO
}

\author{
By
Maiy Mohamed Alsayed Atwa, Wagida Abdel Rahman Anwar , Hasnaa Abdel-al Abouseif and Lamyaa Said AlBagoury \\ Community, Environmental and Occupational Medicine Department, Faculty of Medicine, \\ Ain Shams University \\ Corresponding Author: Maiy Mohamed Alsayed Atwa, \\ E-mail:maiyatwa@yahoo.com
}

\begin{abstract}
Background: Tobacco use is the most leading cause of premature morbidity and mortality. Egyptian sociodemographics have changed affecting the smoking profile which may increase the already alarming smoking situation, especially among university students. This also may delay the governmental efforts to control and decrease the smoking rates.
\end{abstract}

Objectives: This study aimed to: 1) Measure the prevalence of smoking among sample of undergraduate students from selected universities in Cairo. 2) Identify the characteristics associated with smoking among university students.

Design: Descriptive Cross-sectional study was held to assess the prevalence and characteristics of smokers among university students in Cairo.

Setting: The study was held at Governmental and Private Universities, in Cairo Governorate (Egypt) during the academic year 2018-2019.

Subjects and method: A cross-sectional survey was held among convenience sample of 2672 undergraduate university students at Governmental and Private Universities, in Cairo Governorate (Egypt). Data were collected from September 2018 to February 2019. Self-administered questionnaire with 20 questions was developed to assess the prevalence and sociodemographic characteristics associated with smoking among university students.

Results: The prevalence of smoking among the University students' sample was 24.2\%. Shisha and electronic cigarettes were the most common consumed tobacco products among smokers and ex-smokers of the studied sample. The characteristics which significantly associated with tobacco products consumption included male gender, Private Universities and theoretical faculties in addition to high mother's educational level.

Conclusion: The popularity of smoking shisha and electronic cigarettes delay the governmental efforts to control the smoking epidemic.

Key words: Smoking, Shisha, electronic cigarette, undergraduate university students.

\section{INTRODUCTION}

Tobacco use is the most leading cause of early morbidity and mortality. Globally, it caused over 7.1 million deaths in 2016. Many researches have shown that the harmful effects of smoking reach far beyond the well-known lethal consequences of tobacco smoking as cardiovascular diseases, respiratory illness and malignancy. Tobacco consumption 
accelerates the spread of the worldwide epidemic of tuberculosis, and it worsens problems such as mental illness, HIV infection and alcohol abuse (Drope and Schluger, 2018).

Young adults and youths are the vulnerable group which the smoking companies focus on their markets. University students have higher risk to develop smoking habit because they start showing independency; friends have great influence on their behaviors, seeking attraction and popularity as well as being exposed to great social and emotional stresses (Almutairi, 2010 and Halperin et al., 2010).

Egypt is a developing country where tobacco consumption is steadily increasing through years and imposes public health burden (Hanafy et al., 2010). The number of tobacco users has greatly increased in Egypt over the last decade (World Health Organization, 2015). Last Egypt Stepwise Survey 2017 showed that (22.8\%) of the Egyptians older than 18 years old are current tobacco smokers with almost (1.6\%) reduction in smokers' number than the previous survey which was held in 2012 (World Health Organization, 2017).

Egyptian socio-demographics have changed affecting the smoking profile. Shisha smoking remains more prevalent among males although the number of female shisha smokers is increasing nowadays due to increased number of employed women and the exposure to the Western background (Nakkash et al., 2011 and El Awa et al., 2013). The electronic cigarette, a new form of tobacco products, has invaded our community. Unfortunately, electronic cigarette gained popularity among youths because of its favorable flavors and the beliefs of being less harmful than other tobacco products (US Department of Health and Human Services, 2016).

The above-mentioned changes in the Egyptian community may increase the already alarming smoking situation, especially among university students and may delay all governmental efforts to control and decrease the smoking rates. Such findings motivate us to explore the prevalence and corelates of smoking among university students in Cairo, Egypt.

\section{AIM OF THE STUDY}

1. Measure the prevalence of smoking among undergraduate students from selected universities in Cairo.

2. Identify the characteristics associated with smoking among university students.

\section{SUBJECTS AND METHODS}

\section{Study design, setting and Sample:}

A Cross-sectional study was conducted among sample of undergraduate university students attending selected governmental and private universities, in Cairo Governorate (Egypt), from September 2018 to February 2019.

A convenience sample representing students attending the practical faculties (Medicine, Dentistry, Pharmacy, Engineering and Computer Science) and theoretical faculties (Commerce, Law, Political Science, Languages and Mass Communication) in Cairo Governorate's universities participated in the study through the academic year 2018-2019.

Self-reported tobacco products consumption and sociodemographic 
information were collected from $\mathbf{2 6 7 2}$ university students.

Convenience sample was used to select half of the sample from one governmental university and the remaining half from three private universities, then convenience sample of half of the students was selected from the practical faculties and the rest of the sample from theoretical faculties of the previously mentioned universities. This sample size was based on the prevalence rate of smoking among university students in another Egyptian study (El-Sharkawy, 2011) and on the following assumptions using EZR Stata program [R version 3.3.1 (2016-06-21)]: Alpha error $=0.05$ (two sided), $\mathrm{p}=0.075$ for tobacco products consumption, where $\mathrm{p}$ is the proportion of the tobacco products consumers among university students, confidence interval width $=0.02$, and confidence level $=95 . \%$

As this was Self-reporting survey, participants' approval was obtained if they agreed to complete the survey.

Tool: Structured self-administered Arabic language questionnaire with 20 questions was used to collect data from participating students attending the universities. Each participant spent about 10 minutes to complete the following sections:

Section I: Sociodemographic characteristics. These section inquiries about (age, gender, nationality, Parents' educational level, residence, sports and hobbies).

Section II: Smoking status, type of smoked tobacco product and frequency of smoking).

A pilot testing was done among 20 university students to check clarity and adjust the wording of the questionnaire .

\section{Ethical Consideration:}

Official permissions for study conduction were obtained from governmental and private University officials. Also, Ain Shams Research Ethical Committee (REC) approval was obtained and Verbal consent was obtained from study participants before the completion of questionnaire.

\section{Statistical analysis:}

Version 20 of The Statistical Package for the Social Sciences (SPSS) was used for the statistical analysis of this study. Descriptive results (means \pm SD for quantitative data and frequency and percentage for qualitative data) and confidence intervals (95\% CI) were calculated. Chi-squared tests were used to determine associations between sociodemographic factors and tobacco products consumption. The significant level was set at $\mathrm{p}<0.05$

\section{RESULTS}

Characteristics of participants: 2672 university students enrolled in this study aged between (17 and 27) years old with mean age of $(19.7 \pm 1.5 \mathrm{SD}) .58 .6 \%$ of the participants were males, and $41.4 \%$ were females (Table 1). Most of the respondents were raised up by university graduated parents (Figure 1).

The majority of the studied sample were Egyptians (96.7\%) and living with their families $(93.5 \%)$ mainly in Cairo (86.6\%) (Figure 2). 
Table (1): Socio-demographic characteristics of participants $(n=2672)$

\begin{tabular}{|c|c|c|}
\hline Parameters Count & No. & $\%$ \\
\hline $\begin{array}{l}\text { Gender } \\
\text { Male } \\
\text { Female }\end{array}$ & $\begin{array}{l}1567 \\
1105\end{array}$ & $\begin{array}{l}58.6 \% \\
41.4 \%\end{array}$ \\
\hline $\begin{array}{l}\text { Nationality } \\
\text { Egyptian } \\
\text { Non-Egyptian }\end{array}$ & $\begin{array}{l}2585 \\
87\end{array}$ & $\begin{array}{l}96.7 \% \\
3.3 \%\end{array}$ \\
\hline $\begin{array}{l}\text { Living with family } \\
\text { Lived with family } \\
\text { Did not live with family }\end{array}$ & $\begin{array}{l}2498 \\
174 \\
\end{array}$ & $\begin{array}{l}93.5 \% \\
6.5 \% \\
\end{array}$ \\
\hline $\begin{array}{l}\text { working status } \\
\text { Did not work } \\
\text { Worked }\end{array}$ & $\begin{array}{l}1948 \\
724\end{array}$ & $\begin{array}{l}72.9 \% \\
27.1 \%\end{array}$ \\
\hline $\begin{array}{l}\text { Type of work among } \\
\text { worked students }(\mathbf{n}=\mathbf{7 2 4}) \\
\text { Summer vacation } \\
\text { intermittent } \\
\text { Part time job } \\
\text { Full time job }\end{array}$ & $\begin{array}{l}336 \\
198 \\
96 \\
94\end{array}$ & $\begin{array}{l}46.4 \% \\
27.3 \% \\
13.3 \% \\
13 \%\end{array}$ \\
\hline $\begin{array}{l}\text { Sports activity } \\
\text { Did not practice sports } \\
\text { Practiced sports }\end{array}$ & $\begin{array}{l}1688 \\
984\end{array}$ & $\begin{array}{l}63.2 \% \\
36.8 \%\end{array}$ \\
\hline $\begin{array}{l}\text { Having hobby } \\
\text { Did not have hobby } \\
\text { Had a hobby }\end{array}$ & $\begin{array}{l}1800 \\
872\end{array}$ & $\begin{array}{l}67.4 \% \\
32.6 \%\end{array}$ \\
\hline $\begin{array}{l}\text { Age(years): } \\
\text { Minimum } \\
\text { Maximum } \\
\text { Mean } \\
\text { Standard Deviation }\end{array}$ & $\begin{array}{l}17 \\
27 \\
19.7 \\
1.5\end{array}$ & \\
\hline
\end{tabular}




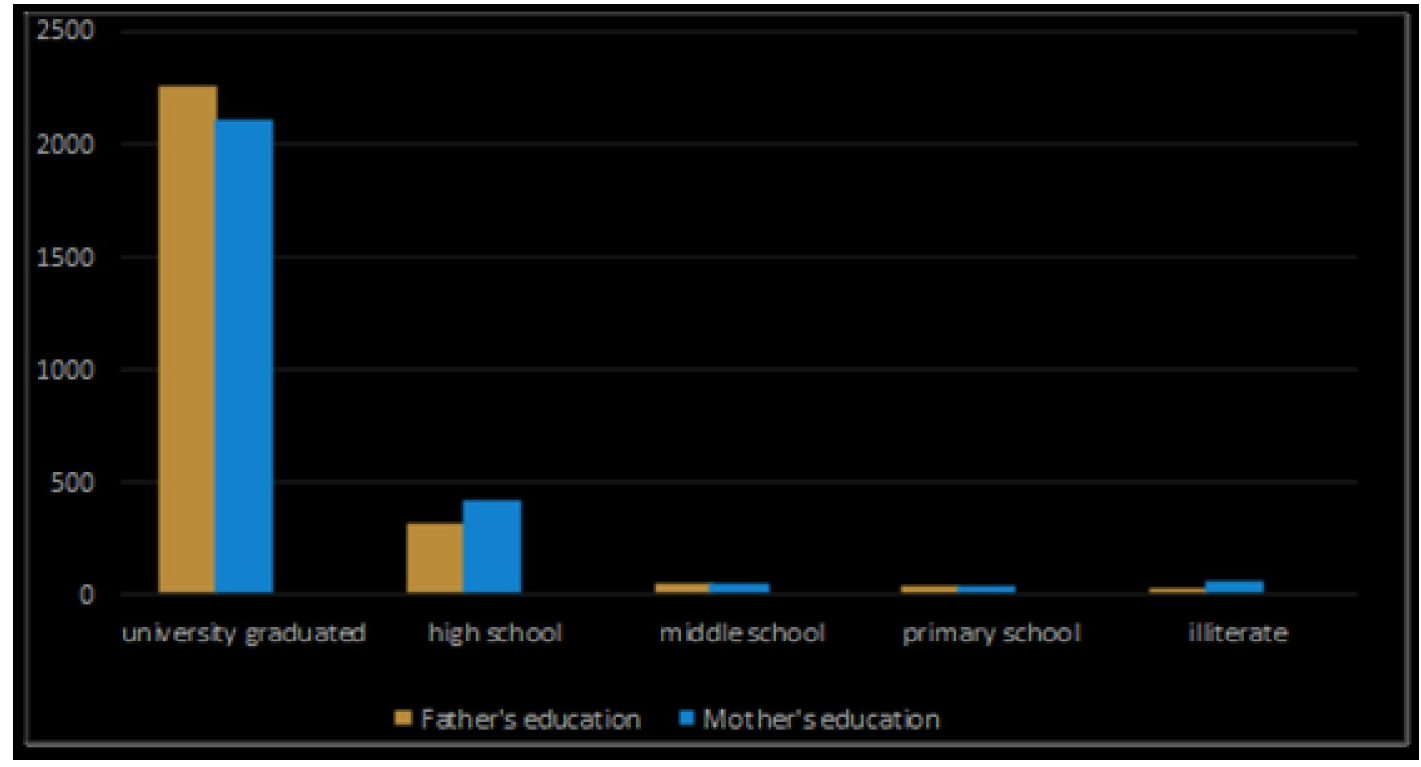

Figure (1): Parents' education level

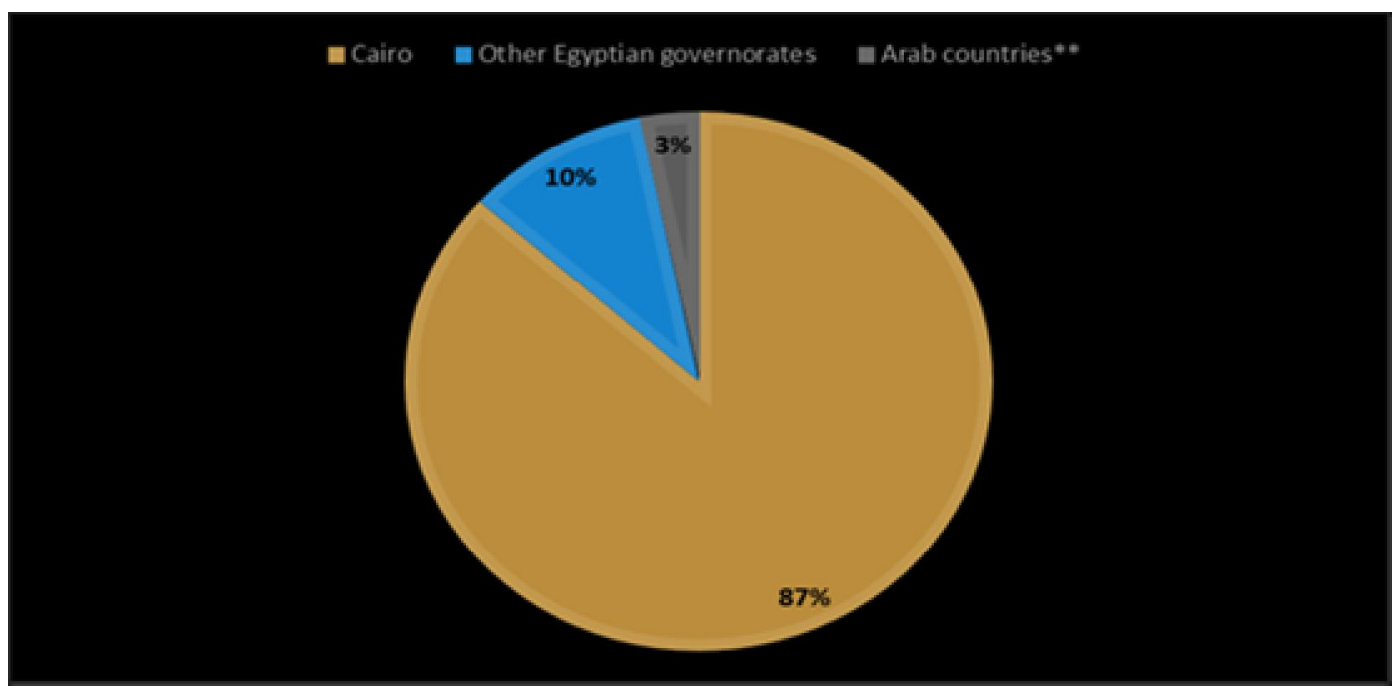

Figure (2): Family residence

*Another Egyptian governorate as: Al Sharqiyah, Suez, Port Saied, El Beheira, Al Minya and Aswan. **Arab countries as: United Arab Emirates, Saudi Arabia, Yemen, Palestine, Iraq and Kuwait.

\section{Prevalence of tobacco products tobacco products among smokers and ex- consumption: The majority of the smokers. Most of the shisha smokers students were non- smokers (71.9\%), smoked shisha at least once weekly. The while smokers represented $24.2 \%$ of the vast majority of manufactured and roll-on sample. Shisha and electronic cigarettes cigarettes smokers used to smoke daily came on the top of the list of consumed between 3 to 50 cigarettes (Table 2).}


Table (2): Tobacco products consumption among the studied sample

\begin{tabular}{|l|l|l|}
\hline Carameters & No. & \% \\
\hline Smoking status: & 1921 & $71.9 \%$ \\
Non-smoker & 104 & $3.9 \%$ \\
Ex-smoker & 647 & $24.2 \%$ \\
\hline Smoker & & \\
\hline Type of tobacco product* smoked by smokers & & \\
and ex-smokers (n=751): & 563 & $75 \%$ \\
Shisha & 444 & $59.1 \%$ \\
Electronic cigarettes & 395 & $52.6 \%$ \\
Manufactured cigarettes & 89 & $11.9 \%$ \\
Roll on cigarettes & 8 & $1.1 \%$ \\
\hline Smokeless tobacco & 352 & $84.6 \%$ \\
\hline Frequency of cigarettes smoking $(\mathbf{n}=\mathbf{4 1 6}):$ & 63 & $15.1 \%$ \\
\hline Daily & & \\
Occasionally & 55 & $9.8 \%$ \\
\hline Frequency of shisha smoking $(\mathbf{n}=\mathbf{5 6 3})$ & 202 & $35.9 \%$ \\
Daily & 196 & $34.8 \%$ \\
2-3 times/week & 110 & $19.5 \%$ \\
\hline Once/week & & \\
<Once/week & 3 & \\
\hline The number of daily smoked cigarettes among & 50 & \\
daily cigarettes smokers (n=352): & 16.8 & \\
Minimum & 7.6 & \\
Maximum & & \\
Mean & & \\
Standard Deviation & & \\
\hline
\end{tabular}

*more than one tobacco product could be answer

Tobacco products consumption and sociodemographic characteristics: Tobacco products consumption was more evident in males $(33.2 \%)$ than females and among Non-Egyptians $(56.3 \%)$ than among Egyptians (23.1\%). No significant differences detected between the smokers and non-smokers as regarding the family residence and living with families (Table $3)$. 
Table (3): Sociodemographic characteristics of smokers:

\begin{tabular}{|c|c|c|c|c|c|c|c|c|c|}
\hline \multirow{2}{*}{ Parameters } & \multirow[t]{2}{*}{ Smoking } & \multicolumn{2}{|c|}{ Smoker } & \multicolumn{2}{|c|}{ Ex-smoker } & \multicolumn{2}{|c|}{ Non-smoker } & \multirow[b]{2}{*}{$\mathbf{X}^{2^{* * *}}$} & \multirow[b]{2}{*}{$\begin{array}{c}P \\
\text { value }\end{array}$} \\
\hline & & No & $\%$ & No & $\%$ & No & $\%$ & & \\
\hline \multirow{2}{*}{ Gender } & $\begin{array}{l}\text { Male } \\
(n=1567)\end{array}$ & 520 & $33.2 \%$ & 64 & $4.1 \%$ & 983 & $62.7 \%$ & \multirow{2}{*}{170.52} & \multirow{2}{*}{$<0.001$} \\
\hline & $\begin{array}{l}\text { Female } \\
(\mathrm{n}=1105)\end{array}$ & 127 & $11.5 \%$ & 40 & $3.6 \%$ & 938 & $84.9 \%$ & & \\
\hline \multirow[b]{2}{*}{ Nationality } & $\begin{array}{l}\text { Egyptian } \\
(\mathbf{n}=2585)\end{array}$ & 598 & $23.1 \%$ & 99 & $3.8 \%$ & 1888 & $73.0 \%$ & \multirow[t]{2}{*}{53.51} & \multirow[t]{2}{*}{$<0.001$} \\
\hline & $\begin{array}{l}\text { Non- } \\
\text { Egyptian } \\
(\mathrm{n}=87)\end{array}$ & 49 & $56.3 \%$ & 5 & $5.7 \%$ & 33 & $37.9 \%$ & & \\
\hline \multirow[t]{2}{*}{$\begin{array}{l}\text { living with } \\
\text { family }\end{array}$} & $\begin{array}{l}\text { With } \\
\text { family } \\
(\mathrm{n}=2498)\end{array}$ & 603 & $24.1 \%$ & 97 & $3.9 \%$ & 1798 & $72.0 \%$ & \multirow[b]{2}{*}{0.13} & \multirow[b]{2}{*}{0.94} \\
\hline & $\begin{array}{l}\text { Alone } \\
(\mathrm{n}=174)\end{array}$ & 44 & $25.3 \%$ & 7 & $4.0 \%$ & 123 & $70.7 \%$ & & \\
\hline \multirow{2}{*}{$\begin{array}{l}\text { family } \\
\text { residence }\end{array}$} & $\begin{array}{l}\text { Cairo } \\
(\mathrm{n}=2313)\end{array}$ & 571 & $24.7 \%$ & 95 & $4.1 \%$ & 1647 & $71.2 \%$ & \multirow[b]{2}{*}{4.76} & \multirow[b]{2}{*}{0.09} \\
\hline & $\begin{array}{l}\text { Other } \\
(\mathbf{n}=359)\end{array}$ & 76 & $21.2 \%$ & 9 & $2.5 \%$ & 274 & $76.3 \%$ & & \\
\hline
\end{tabular}

** Chi-Square test.

Tobacco products consumption and education: Tobacco products consumption was higher among students attended the Private Universities $(27.8 \%)$ and theoretical faculties' students $(28.1 \%)$ than practical faculties' students with significant difference among smokers and non-smokers. Father's educational level didn't show significant difference among different groups, while mother's educational level showed significant difference between smokers and nonsmokers, indicating that the higher the mother's educational level, the higher the probability for her son to acquire the smoking habit (Table 4). 
Table (4): Educational characteristics of smokers:

\begin{tabular}{|c|c|c|c|c|c|c|c|c|c|}
\hline \multirow{2}{*}{\multicolumn{2}{|c|}{ Parameters }} & \multicolumn{2}{|c|}{ Smoker } & \multicolumn{2}{|c|}{ Ex-smoker } & \multicolumn{2}{|c|}{ Non-smoker } & \multirow[b]{2}{*}{$\mathbf{X}^{2}$} & \multirow[b]{2}{*}{$\begin{array}{c}\mathbf{P} \\
\text { value }\end{array}$} \\
\hline & & No & $\%$ & No & $\%$ & No & $\%$ & & \\
\hline \multirow[t]{2}{*}{ University } & \begin{tabular}{|l|}
$\begin{array}{l}\text { Governm- } \\
\text { ental }\end{array}$ \\
\end{tabular} & 276 & $20.7 \%$ & 31 & $2.3 \%$ & 1029 & $77 \%$ & \multirow[t]{2}{*}{40.68} & \multirow[t]{2}{*}{$<0.001$} \\
\hline & Private & 371 & $27.8 \%$ & 73 & $5.5 \%$ & 892 & $66.8 \%$ & & \\
\hline \multirow[t]{2}{*}{ Faculty } & $\begin{array}{l}\text { Theoretic } \\
\text { al } \\
(n=1336)\end{array}$ & 376 & $28.1 \%$ & 49 & $3.7 \%$ & 911 & $68.2 \%$ & \multirow[t]{2}{*}{22.49} & \multirow[t]{2}{*}{$<0.001$} \\
\hline & $\begin{array}{l}\text { Practical } \\
(n=1336)\end{array}$ & 271 & $20 . \%$ & 55 & $4.1 \%$ & 1010 & $75.6 \%$ & & \\
\hline \multirow{4}{*}{$\begin{array}{l}\text { Father's } \\
\text { education }\end{array}$} & $\begin{array}{l}\text { Illiterate } \\
(\mathbf{n}=26)\end{array}$ & 4 & $15.4 \%$ & 0 & $0.0 \%$ & 22 & $84.6 \%$ & \multirow{4}{*}{18.01} & \multirow{4}{*}{0.06} \\
\hline & $\begin{array}{l}\text { Primary } \\
(n=80)\end{array}$ & 15 & $18.7 \%$ & 0 & $0.0 \%$ & 65 & $81.3 \%$ & & \\
\hline & $\begin{array}{l}\text { High } \\
\text { school } \\
(n=312) \\
\end{array}$ & 73 & $23.4 \%$ & 5 & $1.6 \%$ & 234 & $75 \%$ & & \\
\hline & $\begin{array}{l}\text { University } \\
\text { graduated } \\
(\mathrm{n}=2254)\end{array}$ & 555 & $24.6 \%$ & 99 & $4.4 \%$ & 1600 & $71.0 \%$ & & \\
\hline \multirow{4}{*}{$\begin{array}{l}\text { Mother's } \\
\text { education }\end{array}$} & $\begin{array}{l}\text { Illiterate } \\
(\mathrm{n}=57)\end{array}$ & 6 & $10.5 \%$ & 0 & $0.0 \%$ & 51 & $89.5 \%$ & \multirow{4}{*}{31.21} & \multirow{4}{*}{$<0.001$} \\
\hline & $\begin{array}{l}\text { Primary(n } \\
=93)\end{array}$ & 19 & $20.4 \%$ & 2 & $2.1 \%$ & 72 & $77.4 \%$ & & \\
\hline & $\begin{array}{l}\text { High } \\
\text { school } \\
(n=417)\end{array}$ & 99 & $23.7 \%$ & 9 & $2.2 \%$ & 309 & $74.1 \%$ & & \\
\hline & $\begin{array}{l}\text { University } \\
\text { graduated } \\
(\mathrm{n}=2105)\end{array}$ & 523 & $24.8 \%$ & 93 & $4.4 \%$ & 1489 & $70.7 \%$ & & \\
\hline
\end{tabular}

Tobacco products consumption and lifestyle characteristics: Working beside studying showed significance difference among smokers and other groups as smoking was higher among worked university students (39.9\%) especially among those having full time jobs when compared to students who had not work. Practicing sports and having hobbies showed significant differences as both were more common to be found among smokers $(25.5 \%)$ which was slightly higher than those who lack both and used to smoke (23.5\% - Table 5). 
Table (5): Lifestyle characteristics of smokers:

\begin{tabular}{|c|c|c|c|c|c|c|c|c|c|}
\hline \multirow{2}{*}{\multicolumn{2}{|c|}{$\begin{array}{l}\text { Smoking } \\
\text { Parameters }\end{array}$}} & \multicolumn{2}{|c|}{ Smoker } & \multicolumn{2}{|c|}{ Ex-smoker } & \multicolumn{2}{|c|}{ Non-smoker } & \multirow{2}{*}{$\mathbf{X}^{2}$} & \multirow{2}{*}{$P$ value } \\
\hline & & No & $\%$ & No & $\%$ & No & $\%$ & & \\
\hline \multirow{2}{*}{$\begin{array}{l}\text { Working } \\
\text { status }\end{array}$} & \begin{tabular}{|l} 
Did not work \\
$(\mathrm{n}=1948)$
\end{tabular} & 358 & $18.4 \%$ & 68 & $3.5 \%$ & 1522 & $78.1 \%$ & \multirow[t]{2}{*}{143.02} & \multirow[t]{2}{*}{$<0.001$} \\
\hline & $\begin{array}{l}\text { Worked } \\
(n=724)\end{array}$ & 289 & $39.9 \%$ & 36 & $5.0 \%$ & 399 & $55.1 \%$ & & \\
\hline \multirow{4}{*}{$\begin{array}{l}\text { Type of } \\
\text { working }\end{array}$} & $\begin{array}{l}\text { Full time job } \\
(\mathrm{n}=94)\end{array}$ & 48 & $51.1 \%$ & 2 & $2.1 \%$ & 44 & $46.8 \%$ & \multirow{4}{*}{15.30} & \multirow{4}{*}{0.02} \\
\hline & $\begin{array}{l}\text { Part time job } \\
(\mathrm{n}=96)\end{array}$ & 37 & $38.5 \%$ & 2 & $2.1 \%$ & 57 & $59.4 \%$ & & \\
\hline & $\begin{array}{l}\text { Intermittent } \\
(\mathrm{n}=198)\end{array}$ & 81 & $40.9 \%$ & 6 & $3.0 \%$ & 111 & $56.1 \%$ & & \\
\hline & $\begin{array}{l}\text { On summer } \\
\text { vacation only } \\
(n=336)\end{array}$ & 123 & $36.6 \%$ & 26 & $7.7 \%$ & 187 & $55.7 \%$ & & \\
\hline \multirow{2}{*}{$\begin{array}{l}\text { Sports } \\
\text { activity }\end{array}$} & Yes $(n=984)$ & 252 & $25.6 \%$ & 49 & $5.0 \%$ & 683 & $69.4 \%$ & \multirow{2}{*}{7.32} & \multirow{2}{*}{0.03} \\
\hline & No $(n=1688)$ & 395 & $23.4 \%$ & 55 & $3.3 \%$ & 1238 & $73.3 \%$ & & \\
\hline \multirow{2}{*}{$\begin{array}{l}\text { Having } \\
\text { hobby }\end{array}$} & Yes $(n=872)$ & 222 & $25.5 \%$ & 21 & $2.4 \%$ & 629 & $72.1 \%$ & \multirow[t]{2}{*}{8.16} & \multirow{2}{*}{0.02} \\
\hline & No $(n=1800)$ & 425 & $23.6 \%$ & 83 & $4.6 \%$ & 1292 & $71.8 \%$ & & \\
\hline
\end{tabular}

\section{DISCUSSION}

Tobacco products consumption became a public health concern in Egypt as it causes different non communicable diseases which in turn negatively affect the social and economic aspects of the country (World Health Organization, Egypt Stepwise Survey, 2017). This study showed that the prevalence of the smokers among university students was (24.2\%) with prevalence of $(33.2 \%)$ over males. These percentages are greater than those revealed in similar Egyptian study where (16.5\% was the smoking prevalence with $28.9 \%$ prevalence among males) (World Health Organization, 2014) highlighting the smoking epidemic that increases through years. Fortunately, smoking among females remained less than males. This could be due to our conservative cultural traditions which reject the female smoking habit (Fouda et al., 2018). Another study in Saudi Arabia revealed that smoking prevalence among its university students was $9.5 \%$ which is much lower than our study prevalence even if compared our practical faculties students' smoking prevalence to the Saudi's one which was conducted among medical students (Abd El Kader and Al Ghamdi, 2018). The majority of the smokers and ex-smokers in this study preferred smoking shisha $(75 \%)$ and electronic cigarettes $(59 \%)$ most, while 
World Health Organization Survey among university students in 2014 revealed that students preferred smoking cigarettes than shisha. This finding might be due to the effect of the powerful marketing and the social media which represent both as trendy and less harmful to people. The wide spread of this phenomena over years could be also attributed to the belief that shisha is more stylish, a social activity during meetings and less harmful than cigarette smoking (World Health Organization, 2014). Regarding the electronic cigarettes which also became popular among youths because of their availability, variety of flavors, the belief of being safer than combustible tobacco products and the marketing through social media were the reasons behind this popularity (US Department of Health and Human Services, 2016). The number of daily smoked cigarettes among daily cigarettes smokers in this study were slightly lower (16.8) than that recorded in 2014 in similar study which was (20.6) (World Health Organization, 2014). This might reflect the shift of the students toward smoking shisha and electronic cigarettes instead of cigarettes alone. Regarding the higher prevalence of smoking among theoretical faculties' students $(28.1 \%)$ when compared to the practical ones $(20.3 \%)$, these results collectively agreed with another study which revealed that the theoretical faculties students are almost have the double risk to be smokers than practical faculties' students as theoretical faculties' students might have more time to socialize and gathering meetings which mostly accompanied with smoking any type of tobacco products in addition to the exposure to the friends' pressure to smoke. On the other hand, practical faculties' students (Medicine, Pharmacy and Dentistry) are more oriented by the negative social and harmful effects of smoking as they are linked to the scientific field than other students (ElSharkawy, 2011). Mother's educational level had a significant difference and negative impact on descendants acquiring the smoking habit. In this study, the higher the mother's educational level the higher the smoking prevalence among offspring. This study finding matched ElShrakawy study, (2011), as highly educated mother probably busier spending more time in her complicated work than the one with lower educational level. This may lead to lack of familial supervision and weaken the familial bonds which are important to protect the descendants from all hazards especially smoking and addiction as recommended in many studies (Centers for Disease Control and Prevention, 2019). Sometimes, the very busy mother compensates her absence by giving her kids extra money that may spoil them. There was statistical significance in the association between smoking and having job besides studying which agreed with another studies (El-, Almutairi 2011 and, Sharkawy 2010) as the exposure to the adults working life and the availability of the extra pocket money earned from work may encourage the students to tobacco products consumption. Surprisingly, practicing sports and having hobbies was high among smokers this result disagreed with recent study which revealed that practicing sports lowers the probability of young adults to smoke as participating in sports activities and hobbies helps young adults to use their time usefully (Veliz et al., 2017). This 
could be explained as young adults in our community practicing sports either in clubs or in gymnastic centers. Both are opportunity to socialize and meet other peers who have risky behaviors including smoking. In addition, both places don't follow strict rules to prohibit smoking.

\section{LIMITATION OF STUDY}

The current study was limited by:

1. Security restrictions in the universities therefore we used non-random convenience sampling for this study rather than random sampling .

2. Used self-administered questionnaire which may underestimate the real prevalence of smoking among university students.

\section{CONCLUSION}

Shisha smoking and electronic cigarette vaping became phenomena due to recent sociodemographic changes in Egypt.

\section{RECOMMENDATION}

Based on the present study about tobacco products consumption among university students in Cairo, the suggested recommendation can be summarized in the following points :

1. Organize frequent anti-tobacco campaigns in universities and public places with involvement of the students as educators.

2. Develop smoking cessation clinics inside the universities and motivate the students to visit them for free.

3. Set up strict rules to prohibit smoking in public places especially the universities.
4. Introduce compulsory periodic antitobacco workshops for all university students.

5. Raise up the public awareness to the importance of the familial supportive role and super vision to protect our sons and daughters from all hazards including smoking and addiction.

\section{REFERENCES}

1. Almutairi, K. (2010): Tobacco Prevalence among Health Sciences College Students (HSC): Riyadh, Saudi Arabia. Middle East journal of family medicine. 8(7): 10-14.

2. Abd El Kader SM and Al Ghamdi AA. (2018): Smoking Prevalence, Attitude, Knowledge and Practice Among Applied Medical Sciences Saudi Students in King Abdalaziz University. International Journal of Pulmonary and Respiratory Sciences, 2(4):1-9

3. Centers for Disease Control and Prevention. (2019): Smoking and Tobacco Use. Data and Statistics. Fast facts and fact sheets. Youth and Tobacco Use.

4. Drope $J$ and Schluger NW. American Cancer Society. Atlanta. U.S.A. (2018): The Tobacco Atlas. sixth edition. Chapter 78. Page: $26-28$

5. El Awa F, Fouad H, El Naga RA, Emam AH and Labib S. (2013): Prevalence of tobacco use among adult and adolescent females in Egypt. East Mediterr Health J, 19(8):749-54.

6. El-Sharkawy GF. (2011): Cigarette Smoking among University Students: Family- related \& Personal risk factors. Journal of American Scienc.7(3):260- 268.

7. Fouda S, Kelany M, Moustafa N, Abushouk AI, Hassane A, Sleem A, Mokhtar O, Negida $A$ and Bassiony $M$. (2018): Tobacco smoking in Egypt: a scoping literature review of its epidemiology and control measures. EMHJ - 24 (2): 198-215.

8. Halperin A, Smith $S$, Heiligenstein $E$, Brown D and Fleming M. (2010): Cigarette 
smoking and associated health risks among students at five universities. Nicotine Tob Res., 12(2):96-104.

9. Hanafy K, Saleh ASE, Elmallah MEBE, Omar HMA, Bakr D and Chaloupka FJ. (2010): The economics of tobacco and tobacco taxation in Egypt. Paris, France: International Union against Tuberculosis and Lung Disease. Egypt-Report-proof 19-to Vanguard_Egypt Report 12/22/10 10:39 Am. Page 2.

10. Nakkash RT, Khalil $J$ and Afifi RA. (2011): The rise in narghile (shisha, hookah) waterpipe tobacco smoking: a qualitative study of perceptions of smokers and nonsmokers. BMC Public Health, 11(1): article 315 , page $1-9$.

11. US Department of Health and Human Services. (2016): E-Cigarette Use among Youth and Young Adults: A Report of the Surgeon General. Atlanta, GA: US Department of Health and Human Services, Centers for Disease Control and Prevention, National Center for Chronic Disease Prevention and Health Promotion, Office on Smoking and Health. Chapter 2, page 58 \&59.
12. Veliz P, McCabe SE, McCabe VV and Boyd CJ. (2017): Adolescent Sports Participation, E-cigarette Use, and Cigarette Smoking. American Journal of Preventive Medicine. 53(5): e175-e183.

13. World Health Organization. Regional Office for the Eastern Mediterranean. (2014): Shisha and Smokeless Tobacco Use Among University Students in Egypt. WHO EMRO Publication/ Tobacco.

14. World Health Organization. (2015): WHO global report on trends in prevalence of tobacco smoking 2015. Geneva: World Health Organization, Shisha.

15. World Health Organization. Regional Office for the Eastern Mediterranean. (2017): Non communicable diseases and their risk factors. Surveillance. STEPwise approach to chronic disease risk factor surveillance. Country Reports. Egypt 2017 STEPS Survey Report, page 62. 


\section{إتشار التلخين ومحدداته بين طلاب الجامعات في محافظة القاهرة}

مي محمد السيد عطوه - وجيدة عبدالرحمن أنور- حسناء عبدالعال أبوسيف ـ لمياء سعيد الباجوري

قسم طب المجتمع و البيئة و طب الصناعات ـ كلية الطب - جامعة عين شمس

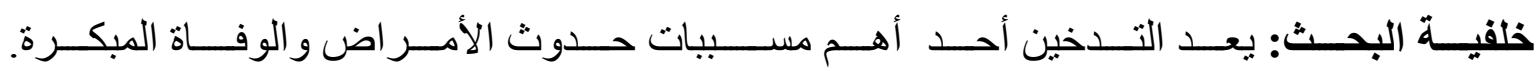

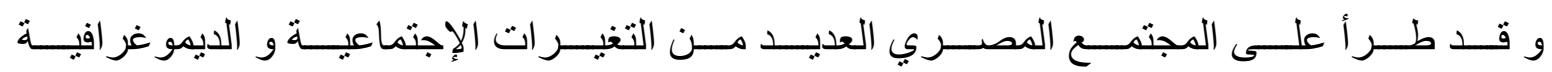

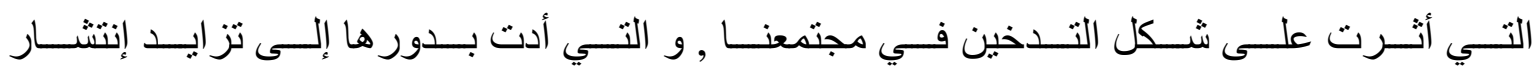

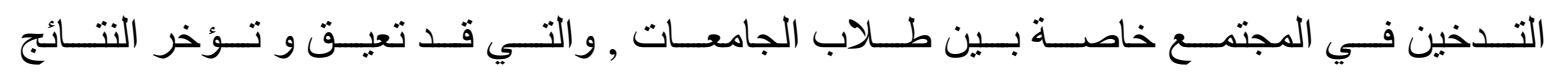
المرجوة من مجهودات الدولة المبذولة للحد من و خفض معدلات التدخين. الغرض من البحث: تهذف هذه الدراسة إلى:

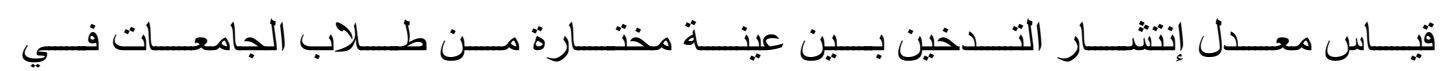
محافظة القاهرة، وتعيين الخصائص المصاحبة للتدخين لطلاب الجامعة المدخنين.

نـــوع الدراســـة: در اســـة مقطعيــة وصــفية بهــدف قيــاس معــدل إنتشـــار التــدخين , تعيـين الخصائص المؤدية للتدخين. مكان الار اسة: جامعة حكومية وثلاث جامعات خاصةة في محافظة القاهرة.

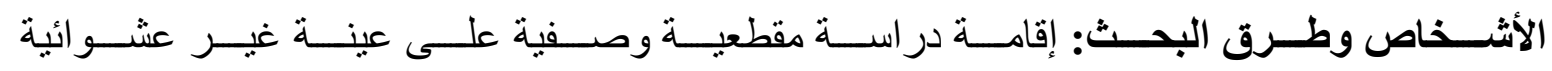

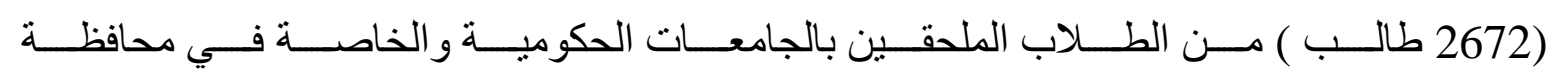

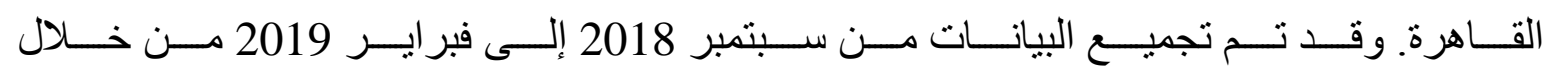

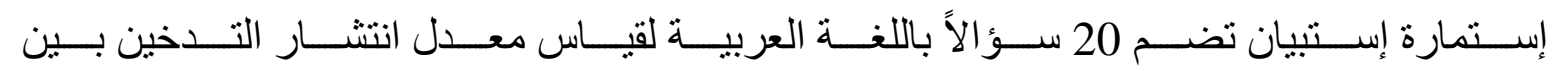

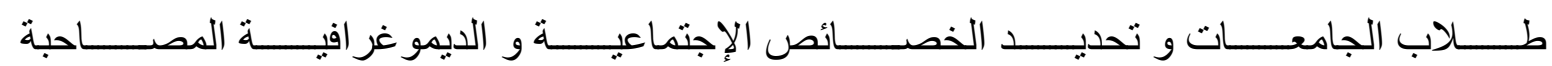
للتدخين.

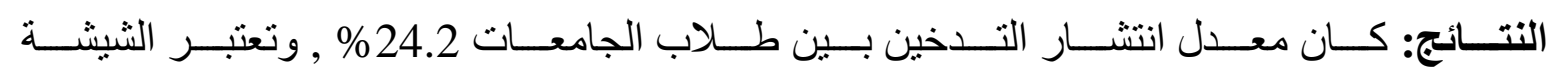

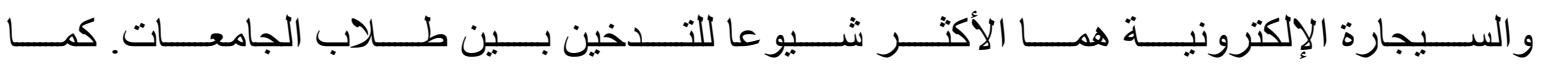




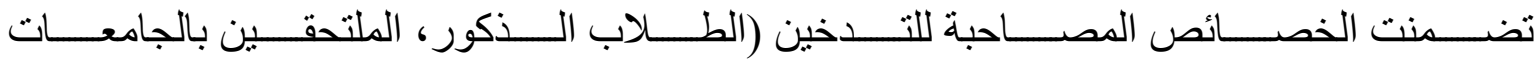
الخاصة و الكليات النظرية) بالإضافة إلى مستوى التعليم العالي للأمهات.

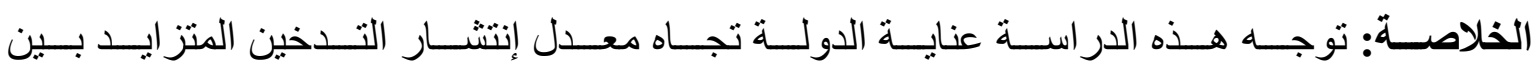

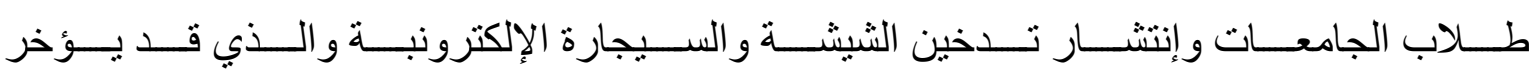
النتائج المرجوة من جهود الدولة المبذولة للحد من إنتشار التدخين. 